\title{
A Study on the Changes of Vocation Training Education Considering the Key Capabilities Required in 21st Century of Fourth Industrial Revolution - Focusing on Architectural Vista Design -
}

\author{
Seong-In Hong ${ }^{1}$ \\ ${ }^{I}$ Adjunct professor, Ph.D. in Architecture, Department of Architecture Engineering, Jeonju Vision \\ University, Korea, architect-hong@ hanmail.net
}

\begin{abstract}
The era of the Fourth Industrial Revolution will replace millions of existing jobs requiring new skill set among future workers. This era requires ten core competencies including complex problem solving, critical thinking, creativity, human resource management, coordinating with others, emotional intelligence, and logical judgment and decision making. To train today's students with these capabilities, it is necessary to change the teaching-learning process of universities. Professors should be equipped with skills to teach a competency-based education. They should be the partners of students to maximize their individual potential and realize their best value. The development of ICT such as the Internet and computers made access to information and knowledge easier. An education that simply conveys knowledge is meaningless. Academic knowledge are now short-lived as knowledge exists as the half-truth. Students accept and memorize simple academic knowledge delivered by professors and they cannot retain them. Changing the teaching-learning process would guarantee a competency-based education to ensure that students will be equipped with the core competencies of the 4IR. This paper studies the education method of universities based on the 4IR core competencies on what changes should be made. Furthermore, it focuses on the architectural vista design, which is a subject for students majoring in urban planning and architectural planning.
\end{abstract}

Keywords: Fourth Industrial Revolution, Vocational Training Education, University Education, Vista Architecture Design, Core competencies

\section{Introduction}

\subsection{Background and Objective of the Study}

The architectural vista design analyzes the effects of colors, spatial shapes, noise, lighting, and traffic lines that composes the urban vista environment through a physical environment survey of the region and reviews local city planning and laws related to architecture and vista, humanities, society, and environment which is important to analyze the direction of improvement of the urban vista environment. In addition, it reflects the architectural plan designed through simulation of the target site and analyzes the problems and improvement plans of the designed building in the surrounding environment. The knowledge required for this are overall knowledge of urban architecture design, urban vista and nature vista environment, review of relevant laws and regulations of local governments, knowledge and understanding of various regulations, and the ability to investigate and 
analyze user requirements. Therefore, it is necessary to summarize the survey, to analyze the contents of the architectural design library, and to analyze natural and physical environments. In the coming era of the Fourth Industrial Revolution, millions of existing jobs disappear and new jobs will be created. This era of the Fourth Industrial Revolution is the transition from a machine-oriented industrial society to a human-centered society.

There are ten competencies required among talents in the future society such as complex problem solving, critical thinking, creativity, people management, coordinating with others, emotional intelligence, judgment and decision making, service orientation, negotiation, and cognitive flexibility. To achieve these, it is necessary to change the traditional teaching-learning process in universities[1].

The purpose of this study is to learn about the changes in vocational training education of universities required in the era of the Fourth Industrial Revolution, which is currently emerging in the society, and to propose an improvement plan based on the architectural vista design established by the Department of the Architecture and Architecture Engineering.

\subsection{Method and Scope of the Study}

This paper is aimed to study the changes in vocational training education of universities required in the era of the Fourth Industrial Revolution, which is currently emerging in the society and to propose an improvement plan based on the architectural vista design eatablished by the Department of the Architecture and Architecture Engineering.

The scope of this study is based on the core competencies of the 21 st century, and in order to understand the urban landscape plan, which is gaining importance due to the current urban landscape policy in the domestic metropolitan area, the architectural landscape opened in the University's Urban Planning Department, Architecture Department, and Architectural Engineering Department.

Pointing out the problems of the existing traditional teaching and learning methods with a focus on design subjects, reestablishing the methodology of teaching and learning methods in the vocational education of universities that need to prepare for the future, and presenting the necessary processes to be used in real universities by analyzing them were the focus of the study.

The method of this study is the study of theory and practice on the design, development, utilization, management and evaluation of courses and resources for learning. The study was based on the teaching method of educational engineering, and the data collection was based on recent data and papers related to the 2016 Davos Forum in Switzerland and the Fourth Revolution.

The programming order of this study is that of Ryu Tae-ho, a professor of educational engineering at Virginia State University in the United States. The 4th Industrial Revolution in 2020 and the design and practice of vocational training courses to development of core competencies in the 21st century were applied to the development of NCS-based curriculum guidelines development, operation, evaluation, and quality control by the Ministry of Education in Korea.

\section{Theoretical Consideration}

\subsection{Definition of the 4th Industrial Revolution}

The World Economic Forum, held in Davos, Switzerland on January 20, 2016, set 'Mastering the Fourth Industrial Revolution' as the main agenda. It was the first time since the foundation of the World Economic Forum that the science and technology field was selected as an agenda in the Davos Forum, which has dealt with economic crisis issues such as low growth, inequality and sustainability. The term 4th Industrial Revolution was first used to mean 'fusion of manufacturing and information and communication' in 'Industry 4.0', one of the top 10 projects of 'High-Tech Strategy 2020' 
announced by Germany in 2010. Since the 4th Industrial Revolution was set as an agenda at the World Economic Forum, the 4th Industrial Revolution and related industries were introduced by many futurists and research institutes around the world after the forum. Klaus Schwab, the advocate of the 4th Industrial Revolution and the Chairman of the World Economic Forum (WEF), wrote in his book "The 4th Industrial Revolution" that the 4IR was based on the 3rd Industrial Revolution. It is defined as a technological revolution in which three technologies, such as bio-industry and physics, rapidly change the economic system and social structure[2]. "We are on the verge of a technological revolution that will fundamentally change the way we live and work. The scale, scope and complexity of this change will be very different from what humanity has experienced before," he said. The 4th Industrial Revolution is characterized as being, 'Hyper-Intelligent', and through ICT technologies such as Internet of Things(IoT) or cloud, it is predicted that humans and humans, things and things, and humans and things will be interconnected and transformed into a more intelligent society with big data and artificial intelligence[3].

\subsection{Changes in Student Evaluation Methods}

Prior to the First Industrial Revolution, the teaching and learning method in universities mainly consisted of mentorship. As in the present, it was not a way for professors to unilaterally transfer knowledge and to evaluate and impose grades on students after a certain period of time.

The professor acted as a mentor to identify and solve the curiosity of individual students, check the class' understanding and learning style, and spend most of the day with students. Accordingly, at that time, it was not important to know which university the students graduated from but rather which professor was his or her mentor.

The First Industrial Revolution, which began in the middle of the 18th century, brought about many changes in society in the late 18th century. One of them was the introduction of a system that paid as much as people worked, similar to that of today. Prior to the First Industrial Revolution, it was a system that received a salary if a certain period of time was filled regardless of performance.

However, as a result of the First Industrial Revolution, the method of paying earnings-based benefits began to expand throughout society. Accordingly, the salary of university professors was also differentially paid according to the number of students teaching. In the existing method, regardless of whether one professor teaches one student or ten students, the mentor's role is paid but the system was changed to the payment of salary in proportion to the number of students.

William Farich, a professor of chemistry at the University of Cambridge, UK, assessed grades in a quantitative way using a method of classifying products in a textile mill by grade, developed and started using it in his classes. This is the beginning of today's university crediting method. He was able to evaluate hundreds of students in a short amount of time thanks to his quantitative methodology, and his salary was significantly higher than other professors.

William Farich's quantitative grade evaluation method has been used in various forms to this day because of its efficiency. The well-known examples are A, B, C, D, and F credits system and 100 points system. In 1830, Harvard University first used the 20-point system, which introduced numbers to quantitative grade evaluation, and then in 1877, the Harvard University introduced a 100-point system by professors of mathematics and philosophy professors.

A, B, C, D, E and F credits were first used at Mount Holyoke College in the United States. Mount Holyoke College gave E grades to scores less than 75 to indicate that the course failed, and to further emphasize the meaning of failing to complete the course, the letter F, the first letter of English word "Failed", was used which means failure after E credit.

The Grade Point Average(GPA) was first used in 1813 at Yale University in the United States. Later, as time passed, a number of universities adopted the current grade evaluation method, which combines 
the average grades of A, B, C, D, F, 100 points system and 4 points system.

The multiple-choice test method for evaluating students has been used for only about 100 years. Before the multiple-choice test was introduced, the professor assessed what the students had to explain in words or sentences. Since the introduction of the first multiple-choice exam by Professor Frederick Kelly of the University of Kansas in the United States, multiple-choice exams have been used worldwide[1].

\subsection{Core Competences of Vocational Training in the 4th Industrial Revolution}

Skills can be divided into hard skills and soft skills. Hard skills refer to the ability to do well in a specific field of work or job, such as welding better than others, stacking bricks well, or attaching tiles well. Soft skills mean the ability to adapt well and demonstrate ability to any work or job that you have not done before. Examples of such soft skills include interpersonal relationships, communication, leadership, creativity, and collaboration skills.

In the era of the changing Fourth Industrial Revolution, more soft skills are required among these two capabilities.

Looking at the characteristics of the 4th Industrial Revolution, it is the era of multi-product smallvolume production. It refers to a GPU that is a non-memory semiconductor, not a CPU, which is a memory semiconductor of a computer. It has changed from enterprise-oriented industry, mass media advertising, technology-oriented, and price-oriented to consumer-oriented era and the industry that maximizes the value of individual-oriented, not machine-oriented advertisements.

In a report published in December 2015 by Foreign Affairs, an international magazine specializing in the international affairs in United States, by Klaus Schwab, $65 \%$ of children entering elementary school in 2016 are expected to work in completely new jobs that never existed.

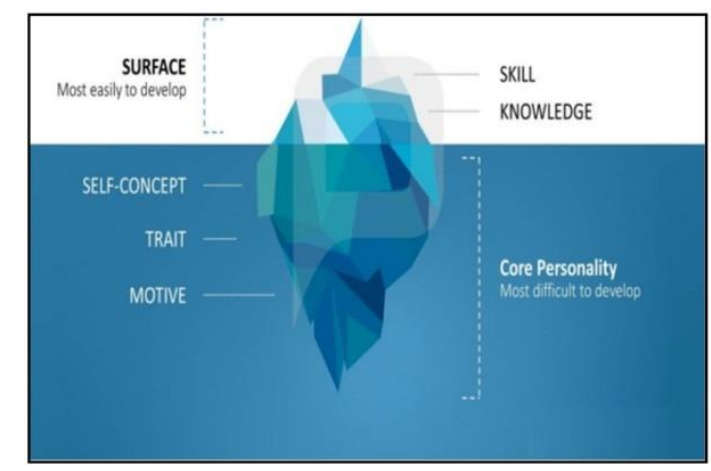

[Fig. 1] Iceberg Model of Competency

The core competencies of the 21 st century in the vocational training education of the 4th Industrial Revolution are having skills on creativity, innovation, critical thinking, information literacy, problemsolving, decision making, flexibility and adaptability, learning to learn, research and inquiry, communication, initiative and self-direction, productivity, leadership and responsibility, collaboration, ICT operations and concepts, digital citizenship, and media literacy[1].

The importance of developing core competencies in the 21 st century in vocational training education during the 4th Industrial Revolution is that the talents of the future society are required to have analytic skills, interpersonal skills, ability to execute, information processing and capacity for change and learning. To do this, first, the analytic skills require the ability to perform critical thinking, problem-solving, decision making, and research and inquiry.

Second, the interpersonal skills require communication, collaboration, leadership and responsibility. Third, the ability to execute requires initiative and self-direction and productivity. 
Fourth, the information processing requires information literacy, media literacy, digital citizenship, and ICT operations and concepts.

Fifth, the capacity for change and learning requires creativity-innovation, flexibility and adaptability and learning to learn[4].

[Table 1] Classification of Five Core Competencies in the 21st Century in the Era of the 4th Industrial Revolution and Vocational Training

\begin{tabular}{c|l}
\hline Core competencies & \multicolumn{1}{c}{ Detail abilities } \\
\hline Analytic skills & $\begin{array}{l}\text { Critical thinking, Problem solving, Decision making } \\
\text { Research and inquiry }\end{array}$ \\
\hline Interpersonal skills & $\begin{array}{l}\text { Communication, Collaboration } \\
\text { Leadership and responsibility }\end{array}$ \\
\hline Ability to execute & Initiative and self-direction, Productivity \\
\hline $\begin{array}{c}\text { Information processing } \\
\text { Capacity for change, } \\
\text { Learning }\end{array}$ & $\begin{array}{l}\text { Information literacy, Media literacy } \\
\text { Digital Citizenship, ICT operations and concepts }\end{array}$ \\
\hline Creativity·innovation, Flexibility and adaptability learning to learn \\
\hline
\end{tabular}

\section{Vocational Training Education during the 4th Industrial Revolution}

\subsection{Characteristics of 21st Century Learners}

According to Professor Ryu Tae-ho's report card without grades, the characteristics of 21 st-century learners are as follows.

First, they are the 'Digital Natives', born in the digital age who have no memory of analog methods, and are good at using internet information and multimedia, and have higher digital literacy than any previous generations. They have a low reluctance to computer or information and communication technology, and they are used to searching the Internet rather than going to the library, and utilize mobile devices such as smartphones, tablet PCs, and laptops.

Second, rather than doing a given task in a certain framework, they plan for themselves and perform self-directed learning in areas of interest. Rather than sitting passively and listening to the teacher-led lessons while studying, they participate in the lessons or learn while working on their own projects to show an active aspect to get better learning effects.

Third, they are problem solvers who enjoy challenges rather than avoiding the given problems. Rather than being lost when facing a complex problem, they try to learn through the process of finding answers while searching for various methods.

Fourth, they are innovators who completely change old customs, organizations, and methods. In order to solve a given complex problem, innovative ideas are derived by utilizing all available surrounding resources. Rather than looking for an answer in a fixed frame, based on one's creativity, he or she wants to derive a completely new correct answer that has never existed, and the learning effect is improved in the process.

Fifth, they are communicators that generate message and deliver to recipients to effectively achieve a specific purpose. Regardless of the online or offline media, they freely make story as the subject of communication. Using mobile devices such as smartphones, tablet PCs, and laptops, they always communicate with others and express their opinions through social networks (SNS) such as Facebook or Instagram, Internet cafes, and blogs and they actively gather opinions of others.

Sixth, they are lifelong learners that the half-life of knowledge and information becomes shorter than that of the parent generation, and the contents that were believed to be correct yesterday can be incorrect today or even a few hours later. In the 4th Industrial Revolution era, the concept of lifelong career has disappeared and as the cycle of finding and moving jobs that could be personally immersed 
and focused became shorter, the importance of lifelong education is increased to support the fast change of careers.

Seventh, being born in the digital age with the development of computer and information and communication technology, they live in an environment where they can find information around the world whenever necessary and naturally develop an international sense. Thanks to the development of the automatic online translation function, the language barrier is further lowered, so information from countries with different languages and cultures can be easily searched and obtained.

Eighth, they are partners who collaborate than learning alone and achieve better learning results. Mobile devices such as smartphones and tablet PCs are always carried in their hands and various information is always exchanged with various friends through mobile devices[1].

\subsection{Changes of the Vocational Training Education during the 4th Industrial Revolution}

Looking at the three elements of competency required in the era of the Fourth Industrial Revolution, it can be divided into work competencies of knowledge and skills and core competency of abilities. When looking up the word competency, there is a word 'competence'. It is said 'competency' and 'competence' can be cross used.

Both these words came from Latin word 'competentia'. But they definitely have different meanings. 'Competency' means confidence or potential ability to do something or an action, and 'competence' means skill or proficiency to actually perform something or action. In other words, 'competence' is visible and measurable, and can be improved through repeated training or practice in a short period of time, but 'competency' is not directly visible to the eyes, so it is not easy to measure and difficult to improve in short term.

In the 4th Industrial Revolution, the vocational training education has evolved from existing teachercentered to learner-centered and provides customized goods and services from one-size-fits-all standardization.

Learners build knowledge by collecting and integrating new information using problem-solving skills through critical thinking and subsequent investigation. In addition, they change from passively accepting information to actively participating[3]. The details are as follows.

First, the professor plays the role of instructing and assisting learning, which used to be responsible for the main task of transmitting and evaluating information and evaluates learners together.

Second, the relationship between professor and learners changed from a separate method of superior and subordinate relationship to give instruction and evaluation to a method in which instruction and evaluation are organically intertwined, and the existing evaluation was used to measure the progress and understanding of learning. In the future, evaluation will focus on diagnosing students' understanding of learning and promoting motivation. Third, in an evaluation based on a learner who only knows the correct answer, an evaluation based on understanding the whole matter through relearning is performed again even if the learner is wrong.

Fourth, while the relationship between the existing learners was extremely individualistic, the relationship between the learners changes collaboratively and cooperatively. Future education should consist of competency-oriented education.

\subsection{Design Curriculum for Core Competency Development}

\section{1) Analytic and Creative Thinking}

First, there is a need for the learners to have the ability to identify, manage, and deal with complex problems, and to exclude reliable and uncertain information by excluding prejudices and preconceptions. 
Second, they should have the ability to find quality information in the flood of information and the ability to analyze and recreate ideas and knowledge.

Third, while undergoing trial and error in the learning process, it is necessary to think about problem solving and eventually solve it and to solve problems by finding various alternative methods.

Fourth, it is not limited to one field, but requires skills that have broad knowledge across the field and a vision to look into the future.

Fifth, they should have the ability to combine several things into one or to re-adjust them for new uses and situations and to solve problems that cannot be solved in a general way.

\section{2) Complex Communication}

First, it is necessary to have the ability to communicate freely with people from different cultures using two or more languages.

Second, the should be able to speak effectively and coherently, and to understand and explain the information that is new.

\section{3) Leadership and Teamwork}

First, it is necessary to have the ability to come up with new ideas and to stimulate emotions so it can gather people's opinions.

Second, they need to have the ability to build trust, resolve conflicts, and strengthen for others, and to bring about consensus through group discussions or meetings and to negotiate results.

Third, they need to have the ability to teach, guide, and counsel on knowledge you know, the ability to get cooperation or seek help from others, and the ability to collaborate and manage groups for work.

Fourth, they need to have the ability to set and execute goals and to achieve the achievements and to share each other's contributions as a result of collaboration.

\section{4) Digital Literacy and Ability}

First, it is necessary to have the ability to understand, utilize and apply digital technology and to create digital knowledge and media.

Second, they need to have the ability to use multimedia resources and to understand and use highlevel mathematics appropriately to effectively convey one's ideas in various formats.

Third, they need to understand traditional or recently emerging fields, such as mathematics, science, technology, environmental science, robotics, geometry, cellular automata, nano technology, and bio technology, etc.

\section{5) Global Visual Approach}

First, it is necessary to have the ability to deal with other people's traditions or values with an open mind and a broad understanding of history, politics, religion, and culture in other regions.

Second, they need to have the ability to freely utilize one or more of the world's commonly used international languages such as English, Chinese, and French, and to use technology to connect people and tasks without being limited to one country or region.

Third, they need to have the ability to properly understand and utilize the humanities and sociological tasks that can effectively search for information across various countries and global issues.

\section{6) Adaptability, Enterprising, Adventurous Spirit}

First, it is necessary to have the develop flexibility, agility and adaptability, the challenge and experiment in an unfamiliar situation, and the ability to explore and experiment.

Second, they need to have the ability to develop a spirit of independence and to develop the 
knowledge and competencies necessary to run a company through operation of small business startups.

\section{7) Integrity and Ethical Decision Making}

First, necessary to have the ability to sustain a sympathetic and understanding perspective and the ability to cultivate integrity, honesty, fairness and respect.

Second, they need to have the ability to exercise moral courage when faced with an unfair situation, and to exercise and act ethically and morally for the benefit and happiness of the community.

Third, they need to have the ability to understand the ethical issues and dilemma of new media and new technologies is essential.

\section{8) Mind Habits and Mindset}

It is necessary to have integrity, creativity, a heart of learning and curiosity, persistence and patience, self-esteem, self-stress management and time management skills.

\section{Architectural Vista Design Curriculum Class Design for Core Competency Development}

\subsection{Definition of Core Competencies}

Architectural vista design for core competency development curriculum defines six types of analytical thinking, communication, collaboration, digital communication, open mind and ethical thinking as necessary for class design.

[Table 2] Building Vista Core Competencies

\begin{tabular}{c|l|c|c}
\hline no & \multicolumn{1}{|c|}{ Core Competencies(Details) } & $\begin{array}{c}\text { Architectural Vista } \\
\text { Environmental Analysis }\end{array}$ & $\begin{array}{c}\text { Architectural Vista } \\
\text { Design(30H) }\end{array}$ \\
\hline 1 & $\begin{array}{l}\text { Analytical Thinking(Problem solving, information } \\
\text { searching, situation adjustments) }\end{array}$ & Primary Outcome & Primary Outcome \\
\hline 2 & Communication(Effective communication) & & Primary Outcome \\
\hline 3 & Collaboration (division, time management) & Primary Outcome & Primary Outcome \\
\hline 4 & Digital Communication(Use of technology) & & Primary Outcome \\
\hline 5 & Open mind(Understand cultural acceptance) & Secondary Outcome & \\
\hline 6 & Ethical Thinking(Ethical decision for the community) & & Primary Outcome \\
\hline
\end{tabular}

The class design consists of 15 hours for architectural vista environment analysis and 30 for architectural vista design, a total of 45 hours and three credits to each semester. Other details are shown in [Table 2].

\subsection{Learning Goal Setting}

Learning goal setting means to protect the historic city vista of the past and analyze ways to improve the urban vista environment in the future through the physical environment survey of the region and the related laws, humanities, and socio-environmental survey in the architectural vista environment analysis. It was determined that analytical thinking, collaboration, and open thinking would be needed as the core competencies. In the architectural vista design, it is necessary to use analytical thinking, collaboration, and digital communication as core competencies through the educational goal of designing the architectural plan through simulation of the surrounding physical environment according to the architectural vista design concept.In addition, the educational goal of designing an improvement 
plan for coordination of architectural plans to reflect the unified characteristics of the region and to improve the aesthetic and functional vista environment that require analytic thinking, communication, collaboration, digital thinking, and ethical awareness. The key competencies for learning objectives are shown in [Table 3].

[Table 3] Set Learning Objectives

\begin{tabular}{|c|c|c|c|c|c|}
\hline Course & Unit & Learning objective & $\begin{array}{c}\text { Core } \\
\text { competency }\end{array}$ & $\begin{array}{c}\text { Core } \\
\text { competency } \\
\text { factors }\end{array}$ & $\begin{array}{l}\text { Core competency } \\
\text { learning objective }\end{array}$ \\
\hline \multirow{12}{*}{$\begin{array}{l}\text { Architectural } \\
\text { Vista Design }\end{array}$} & \multirow{4}{*}{$\begin{array}{l}\text { Architectural } \\
\text { Vista } \\
\text { Environmental } \\
\text { Analysis }\end{array}$} & \multirow{4}{*}{$\begin{array}{l}\text { It is possible to } \\
\text { analyze the } \\
\text { improvement of the } \\
\text { Vista environment } \\
\text { through the } \\
\text { investigation of the } \\
\text { local physical } \\
\text { environment and } \\
\text { the related laws, } \\
\text { humanities, and } \\
\text { social environment. }\end{array}$} & & $\begin{array}{l}\text { Understand } \\
\text { and process } \\
\text { problem }\end{array}$ & \multirow{2}{*}{$\begin{array}{l}\text { To train information } \\
\text { searching and problem- } \\
\text { handling skills through } \\
\text { the review of related data } \\
\text { and the review of laws } \\
\text { related to the current } \\
\text { situation in areas where } \\
\text { urban development has } \\
\text { been conducted. }\end{array}$} \\
\hline & & & $\begin{array}{l}\text { Analytical } \\
\text { Thinking }\end{array}$ & $\begin{array}{l}\text { Information } \\
\text { searching }\end{array}$ & \\
\hline & & & Collaboration & $\begin{array}{l}\text { Division, } \\
\text { time } \\
\text { management }\end{array}$ & $\begin{array}{l}\text { Develop effective } \\
\text { division of work and time } \\
\text { management ability to } \\
\text { submit in accordance } \\
\text { with deadline. }\end{array}$ \\
\hline & & & Open mind & $\begin{array}{l}\text { Respect } \\
\text { customs and } \\
\text { values of } \\
\text { others }\end{array}$ & $\begin{array}{l}\text { Draw directions for } \\
\text { improvement in } \\
\text { consideration of local } \\
\text { identity and cultural } \\
\text { ideas. }\end{array}$ \\
\hline & \multirow{8}{*}{$\begin{array}{l}\text { Architectural } \\
\text { Vista Design }\end{array}$} & \multirow{3}{*}{$\begin{array}{l}\text { According to the } \\
\text { architectural Vista } \\
\text { design concept, the } \\
\text { architectural plan } \\
\text { can be designed } \\
\text { through simulation, } \\
\text { that is the analysis } \\
\text { of the surrounding } \\
\text { physical } \\
\text { environment. }\end{array}$} & $\begin{array}{l}\text { Analytical } \\
\text { Thinking }\end{array}$ & $\begin{array}{l}\text { Understand } \\
\text { and process } \\
\text { problem }\end{array}$ & $\begin{array}{l}\text { Train analytical thinking } \\
\text { through a Vista } \\
\text { architecture design } \\
\text { considering the } \\
\text { architectural style and } \\
\text { historicity of the } \\
\text { surrounding buildings. }\end{array}$ \\
\hline & & & Division & $\begin{array}{l}\text { Division, } \\
\text { time } \\
\text { management }\end{array}$ & $\begin{array}{l}\text { Train effective division } \\
\text { of work and time } \\
\text { management ability to } \\
\text { submit in accordance } \\
\text { with deadline. }\end{array}$ \\
\hline & & & $\begin{array}{c}\text { Digital } \\
\text { communication }\end{array}$ & $\begin{array}{l}\text { Utilize digital } \\
\text { technology }\end{array}$ & $\begin{array}{l}\text { Operates various digital } \\
\text { software necessary for } \\
\text { design. }\end{array}$ \\
\hline & & \multirow{5}{*}{$\begin{array}{l}\text { It is possible to } \\
\text { design a plan to } \\
\text { improve the } \\
\text { coordination of } \\
\text { architectural plans } \\
\text { to reflect the unified } \\
\text { characteristics of } \\
\text { the region and to } \\
\text { improve the } \\
\text { aesthetic and } \\
\text { functional Vista } \\
\text { environment. }\end{array}$} & $\begin{array}{l}\text { Analytical } \\
\text { Thinking }\end{array}$ & $\begin{array}{l}\text { Propose idea } \\
\text { and adjust } \\
\text { situation }\end{array}$ & $\begin{array}{l}\text { Design activities such as } \\
\text { architectural Vista } \\
\text { planning considering the } \\
\text { context of urban Vistas. }\end{array}$ \\
\hline & & & Communication & $\begin{array}{l}\text { Effective } \\
\text { delivery }\end{array}$ & $\begin{array}{l}\text { The architectural model } \\
\text { and the bird's-eye view } \\
\text { are used as various } \\
\text { expressions for the } \\
\text { presentation. }\end{array}$ \\
\hline & & & Division & $\begin{array}{l}\text { Division, } \\
\text { time } \\
\text { management }\end{array}$ & $\begin{array}{l}\text { Develop effective } \\
\text { division of work and time } \\
\text { management ability to } \\
\text { submit in accordance } \\
\text { with deadline. }\end{array}$ \\
\hline & & & $\begin{array}{l}\text { Digital } \\
\text { Thinking }\end{array}$ & $\begin{array}{l}\text { Utilize digital } \\
\text { technology }\end{array}$ & $\begin{array}{l}\text { Operates various digital } \\
\text { software necessary for } \\
\text { design. }\end{array}$ \\
\hline & & & $\begin{array}{c}\text { Ethical } \\
\text { awareness }\end{array}$ & $\begin{array}{c}\text { Ethical } \\
\text { decision for } \\
\text { the benefit of }\end{array}$ & $\begin{array}{l}\text { Instead of pursuing the } \\
\text { interests of the building } \\
\text { owner, the city }\end{array}$ \\
\hline
\end{tabular}




\begin{tabular}{l|l|l|l|l}
\hline & & & the \\
community & $\begin{array}{l}\text { community aims to } \\
\text { reduce the stress of the } \\
\text { city through } \\
\text { consideration of the } \\
\text { space of others. }\end{array}$ \\
\hline
\end{tabular}

\subsection{Mapping of the Overall Learning Process}

The overall learning process is classified into architectural vista environment analysis and architectural course design. The mapping is shown in [Table 4].

[Table 4] Mapping the Entire Learning Process

\begin{tabular}{|c|c|c|c|c|c|}
\hline \multirow[b]{3}{*}{ Core competenc } & & \multirow[b]{3}{*}{$\begin{array}{l}\text { Core competency } \\
\text { factor }\end{array}$} & \multicolumn{3}{|c|}{ Compliance } \\
\hline & & & \multirow{2}{*}{$\begin{array}{l}\begin{array}{c}\text { Architectural Vista } \\
\text { Environmental } \\
\text { Analysis }\end{array} \\
\text { It is possible to } \\
\text { analyze the } \\
\text { improvement of the } \\
\text { Vista environment } \\
\text { through the } \\
\text { investigation of the } \\
\text { local physical } \\
\text { environment and the } \\
\text { related laws, } \\
\text { humanities, and social } \\
\text { environment. }\end{array}$} & \multicolumn{2}{|c|}{ Architectural Vista Design } \\
\hline & & & & $\begin{array}{l}\text { According to the } \\
\text { architectural Vista } \\
\text { design concept, the } \\
\text { architectural plan can } \\
\text { be designed through } \\
\text { simulation that is the } \\
\text { analysis of the } \\
\text { surrounding physical } \\
\text { environment. }\end{array}$ & $\begin{array}{l}\text { It is possible to design } \\
\text { a plan to improve the } \\
\text { coordination of } \\
\text { architectural plans to } \\
\text { reflect the unified } \\
\text { characteristics of the } \\
\text { region and to improve } \\
\text { the aesthetic and } \\
\text { functional Vista } \\
\text { environment. }\end{array}$ \\
\hline \multirow{3}{*}{$\begin{array}{l}\text { Analytical } \\
\text { Thinking }\end{array}$} & \multirow{3}{*}{$\mathrm{P}$} & $\begin{array}{c}\text { Ability to } \\
\text { understand and } \\
\text { process problem }\end{array}$ & $\begin{array}{l}\text { To train information } \\
\text { searching and } \\
\text { problem-handling } \\
\text { skills through the } \\
\text { review of related data } \\
\text { and the review of laws } \\
\text { related to the current } \\
\text { situation in areas } \\
\text { where urban } \\
\text { development has been } \\
\text { conducted. }\end{array}$ & $\begin{array}{l}\text { A Vista architecture } \\
\text { design considering the } \\
\text { architectural style and } \\
\text { historicity of the } \\
\text { surrounding } \\
\text { buildings. }\end{array}$ & \\
\hline & & $\begin{array}{l}\text { Ability to find } \\
\text { information }\end{array}$ & $\begin{array}{l}\text { To train information } \\
\text { searching and } \\
\text { problem-handling } \\
\text { skills through the } \\
\text { review of related data } \\
\text { and the review of laws } \\
\text { related to the current } \\
\text { situation in areas } \\
\text { where urban } \\
\text { development has been } \\
\text { conducted. }\end{array}$ & & \\
\hline & & $\begin{array}{l}\text { Propose idea and } \\
\text { adjust situation }\end{array}$ & & & $\begin{array}{l}\text { Design activities such } \\
\text { as architectural Vista } \\
\text { planning considering } \\
\text { the context of urban } \\
\text { Vistas. }\end{array}$ \\
\hline Communication & $\mathrm{P}$ & $\begin{array}{l}\text { Ability to speak } \\
\text { effectively }\end{array}$ & & & $\begin{array}{l}\text { The architectural } \\
\text { model and the bird's- } \\
\text { eye view are used as } \\
\text { various expressions } \\
\text { for the presentation. }\end{array}$ \\
\hline
\end{tabular}




\begin{tabular}{|c|c|c|c|c|c|}
\hline \multirow[b]{2}{*}{ Team Work } & \multirow[b]{2}{*}{$\mathrm{P}$} & $\begin{array}{c}\text { Ability to gain } \\
\text { cooperation or help } \\
\text { of others }\end{array}$ & $\begin{array}{l}\text { Effective division of } \\
\text { work and enhance } \\
\text { teamwork through } \\
\text { division of work }\end{array}$ & $\begin{array}{l}\text { Effective division of } \\
\text { work and enhance } \\
\text { teamwork through } \\
\text { division of work }\end{array}$ & $\begin{array}{l}\text { Effective division of } \\
\text { work and enhance } \\
\text { teamwork through } \\
\text { division of work }\end{array}$ \\
\hline & & $\begin{array}{l}\text { Time management } \\
\text { ability }\end{array}$ & $\begin{array}{l}\text { Train time } \\
\text { management ability by } \\
\text { submitting within the } \\
\text { deadline through } \\
\text { division of work. }\end{array}$ & $\begin{array}{l}\text { Train time } \\
\text { management ability } \\
\text { by submitting within } \\
\text { the deadline through } \\
\text { division of work. }\end{array}$ & $\begin{array}{l}\text { Train time } \\
\text { management ability by } \\
\text { submitting within the } \\
\text { deadline through } \\
\text { division of work. }\end{array}$ \\
\hline $\begin{array}{c}\text { Digital } \\
\text { Communication }\end{array}$ & $\mathrm{P}$ & $\begin{array}{c}\text { Ability to } \\
\text { understand, utilize, } \\
\text { and apply digital } \\
\text { technology }\end{array}$ & & $\begin{array}{l}\text { Operates various } \\
\text { digital software } \\
\text { necessary for design. }\end{array}$ & $\begin{array}{l}\text { Operates various } \\
\text { digital software } \\
\text { necessary for design. }\end{array}$ \\
\hline Open Mind & S & $\begin{array}{l}\text { Ability to develop } \\
\text { open mind about } \\
\text { other people's } \\
\text { traditions and } \\
\text { values }\end{array}$ & $\begin{array}{l}\text { Derive improvement } \\
\text { plans that take into } \\
\text { account local } \\
\text { identities and cultural } \\
\text { ideas. (S) }\end{array}$ & & \\
\hline $\begin{array}{c}\text { Ethical } \\
\text { Awareness }\end{array}$ & $\mathrm{P}$ & $\begin{array}{l}\text { Ability to make } \\
\text { ethical and rational } \\
\text { decision for the } \\
\text { benefit of the } \\
\text { community }\end{array}$ & & & $\begin{array}{l}\text { Instead of pursuing } \\
\text { the interests of the } \\
\text { building owner, the } \\
\text { city community aims } \\
\text { to reduce the stress of } \\
\text { the city through } \\
\text { consideration of the } \\
\text { space of others. }\end{array}$ \\
\hline
\end{tabular}

\subsection{Course Design}

In the course design, as a teaching and learning method for the development of analytical thinking in environmental analysis of architectural vistas, the goal is set to 'Cultivate information searching ability and problem-handling ability through review of related data and review of various laws related to the current status of areas where urban development has progressed' to proceed with teaching and learning methods, and conduct literature research in a teaching method. The evaluation method consists of portfolio and oral presentation. Other details are shown in [Table 5].

[Table 5] Class Design

\begin{tabular}{|c|c|c|c|c|c|}
\hline Unit & Contents & Core competency & teaching and learning method & $\begin{array}{l}\text { Teaching } \\
\text { method }\end{array}$ & $\begin{array}{l}\text { Evaluation } \\
\text { method }\end{array}$ \\
\hline \multirow{3}{*}{$\begin{array}{l}\text { Architectural } \\
\text { Vista } \\
\text { Environmental } \\
\text { Analysis }\end{array}$} & \multirow{3}{*}{$\begin{array}{l}\text { It is possible to } \\
\text { analyze the } \\
\text { improvement } \\
\text { of the Vista } \\
\text { environment } \\
\text { through the } \\
\text { investigation } \\
\text { of the local } \\
\text { physical } \\
\text { environment } \\
\text { and the related } \\
\text { laws, } \\
\text { humanities, } \\
\text { and social } \\
\text { environment. }\end{array}$} & $\begin{array}{l}\text { Analytical } \\
\text { Thinking } \\
\text { (understand and } \\
\text { process problems, } \\
\text { search for } \\
\text { information) }\end{array}$ & $\begin{array}{l}\text { To train information searching } \\
\text { and problem-handling skills } \\
\text { through the review of related data } \\
\text { and the review of laws related to } \\
\text { the current situation in areas } \\
\text { where urban development has } \\
\text { been conducted. }\end{array}$ & $\begin{array}{l}\text { Literature } \\
\text { search }\end{array}$ & \multirow{5}{*}{$\begin{array}{l}\text { Portfolio and } \\
\quad \text { oral } \\
\text { presentation }\end{array}$} \\
\hline & & Collaboration & $\begin{array}{l}\text { Develop effective division of } \\
\text { work and time management } \\
\text { ability to submit in accordance } \\
\text { with deadline. }\end{array}$ & $\begin{array}{l}\text { Group } \\
\text { presentation }\end{array}$ & \\
\hline & & Open mind & $\begin{array}{l}\text { Derive improvement plans that } \\
\text { take into account local identities } \\
\text { and cultural ideas. }\end{array}$ & $\begin{array}{c}\text { Make } \\
\text { planning }\end{array}$ & \\
\hline \multirow[t]{2}{*}{$\begin{array}{l}\text { Architectural } \\
\text { Vista Design }\end{array}$} & \multirow{2}{*}{$\begin{array}{l}\text { According to } \\
\text { the } \\
\text { architectural } \\
\text { Vista design } \\
\text { concept, the } \\
\text { architectural } \\
\text { plan can be }\end{array}$} & $\begin{array}{l}\text { Analytical } \\
\text { Thinking }\end{array}$ & $\begin{array}{l}\text { Train analytical thinking through } \\
\text { a Vista architecture design } \\
\text { considering the architectural style } \\
\text { and historicity of the surrounding } \\
\text { buildings. }\end{array}$ & $\begin{array}{l}\text { Literature } \\
\text { search }\end{array}$ & \\
\hline & & Collaboration & $\begin{array}{l}\text { Train effective division of work } \\
\text { and time management ability to }\end{array}$ & $\begin{array}{l}\text { Group } \\
\text { presentation }\end{array}$ & \\
\hline
\end{tabular}




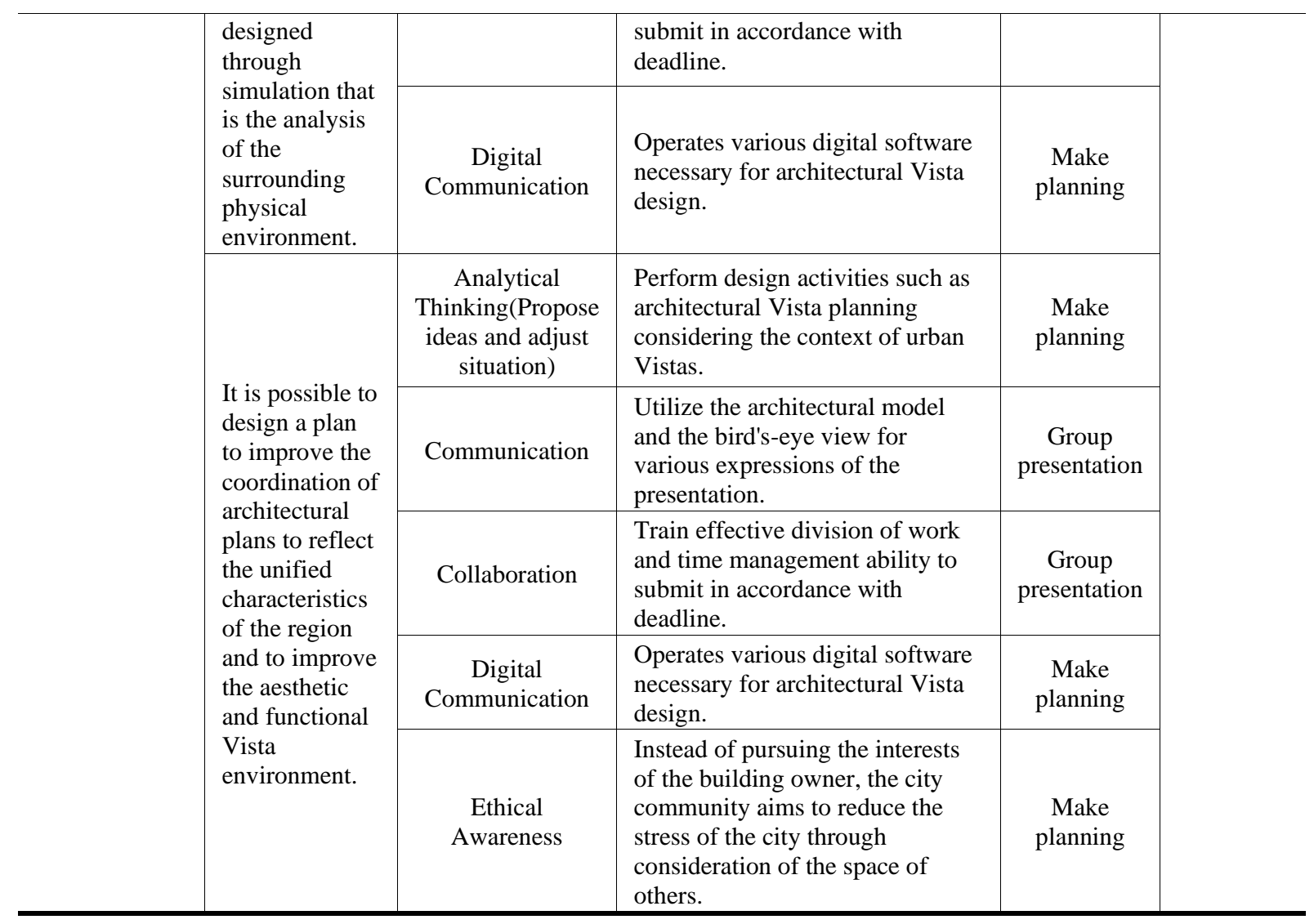

\subsection{Self-learning Method of Professor}

\section{1) Core Competency Teaching Method}

The 4th Industrial Revolution era is a hyper-connected society and everyone is in a flood of information. In order to live independently in such a society, it is necessary to train talents with critical thinking skills, creativity, mutual cooperation, autonomy of communication, and problem-solving skills.

The teaching capacity required is as follows. First, learning planning requires the ability to establish learning objectives for teachers and to design and develop educational content. Second, learning practice requires the ability to effectively implement the planned teaching and learning process. Third, learning management needs the ability to effectively and efficiently manage various elements for systematic teaching and learning. Fourth, learning activity support needs the ability to support learners and promote learning activities in order to improve their learning ability. Professors who have to perform these various roles must take the core competency teaching method class for effective operation of the educational program as a self-learning method.

\section{2) NCS Basic Vocational Skills Online Lecture}

The government has established the National Competency Standard (NCS) called 'Competencyoriented social realization', which is a national job competency standard that systematically organizes the demands of knowledge, skills, and attitudes required to successfully perform a job in an industrial field by industry sector and level. NCS can be used as a core mechanism in training talents with job performance through customized training for industrial demand. The university has been able to develop job-oriented talents that can be directly put into the field by using NCS to introduce fieldoriented training courses that reflect the needs of industrial sites. In addition, by actively preparing for talent-based and job-oriented recruitment, efforts should be made not only to improve major skills but 
also to improve basic skills[5]. NCS-based basic vocational competency refers to the basic and common vocational competency required to successfully perform the job in any company or job regardless of the company's characteristics, gender, and rank. Basic vocational skills are common skills that must be educated in higher education institutions regardless of major education and liberal arts education. These basic vocational skills are divided into 10 domains and composed each of subcompetence, as shown in Table 6. The professor must take the NCS basic vocational skills online lecture for effective operation of the educational program by self-learning method[6].

[Table 6] Scope and Sub-competencies of the Basic Vocational Competency

\begin{tabular}{c|l}
\hline $\begin{array}{c}\text { Areas of basic vocational } \\
\text { competency }\end{array}$ & \multicolumn{1}{c}{ Sub-competencies } \\
\hline Communications & Understand documents, draft documents, listening, expressing, basic foreign language \\
\hline Mathematics & Basic mathematics, basic statistics, chart analysis, making chart \\
\hline Problem solving & Thinking, problem solving \\
\hline Self-development & Self-recognition, self-management, career development \\
\hline Resource management & $\begin{array}{l}\text { Time, resource management, budget resource management, material resource management, } \\
\text { human resource management }\end{array}$ \\
\hline Relationship & Team-work, leadership, conflict management, customer service \\
\hline Information & Computer skill, information processing \\
\hline Technology & Understanding technology, selecting technology, technology application \\
\hline Understanding organization & $\begin{array}{l}\text { International sense, understanding organizational structure, understanding business } \\
\text { management, understanding assigned task }\end{array}$ \\
\hline Work ethics & Work ethics, community ethics \\
\hline
\end{tabular}

\subsection{Class Evaluation}

The evaluation method of this core competency-oriented architectural vista design program combines portfolio evaluation and oral presentation. The intermediate assessment analyzes the environmental analysis of the surrounding city vista through the physical environment survey of the region, various related laws and regulations, and humanistic and sociological approaches through simulation, creates and submits a portfolio, and presents for presentation. The evaluation indices are, first, determine whether the items are exemplified in the Ministry of Land, Infrastructure and Transport's basic vista planning. Second, they determine whether or not simulation processing is performed in consideration of Vista in the surrounding area. Third, the indices select four or more viewpoints to determine whether they have been properly analyzed. Fourth, it is determined whether or not the final result is printed and submitted within 10 sheets of A3 paper.

The final evaluation takes into account the urban vista of the area, simulates the area's history and climate, and vista plans that take into account future urban development, and simulates them, submits portfolios and presents them. The evaluation indices first check, whether it is an architectural design that takes into account the vista of the city. Second, it the indices examine whether the relevant laws such as the National Land Use and Planning Act, the Landscape Act, the Construction Act, and the Public Design Promotion Act have been properly reviewed and whether or not the plan has been applied.

Third, the indices determine whether it is an architectural design that considers the surrounding history and identity in consideration of the existing urban order. Fourth, the final result should be printed out within 10 sheets of A3 paper, and confirmed through oral presentations to clearly express the purpose and intention of the building plan. The detailed evaluation criteria of the final result are as follows. 
[Question] Is it an architectural vista design that takes into account the existing urban order and the surrounding history and identity?

[Table 7] Rubric

\begin{tabular}{c|l}
\hline Standard & \multicolumn{1}{c}{ Contents } \\
\hline High & $\begin{array}{l}\text { The architectural vista design considering the urban identity and history, the existing urban order, and the mass } \\
\text { plan, color plan, external material finishing plan, vistaing plan, and public notice plan were conducted. }\end{array}$ \\
\hline Medium & $\begin{array}{l}\text { Insufficient consideration of urban identity and history, and architectural vista design considering architecture } \\
\text { style and mass plan, color plan, external material finishing plan, vistaing plan, public notice plan, etc., taking } \\
\text { into account the existing urban order. }\end{array}$ \\
\hline Low & $\begin{array}{l}\text { The identity of the city and the history are insufficient, and the architecture is not heterogeneous considering the } \\
\text { existing urban order, but rather a landmark character rather than considering harmony with surrounding } \\
\text { buildings. }\end{array}$ \\
\hline
\end{tabular}

\section{Conclusion}

In competency-oriented education, the subject of learning is the student. Since each student sets his or her own learning goals and progresses sequentially, there is no need to compare individual students' grades or ranks. In order to maximize the learning effect, the most important thing is to induce learning motivation, and when students learn curiosity and interests themselves, the level of immersion in lectures increases and the learning results improve.

Professors practicing competency-based education are mentors coaching learners as partners to help them learn and maximize their potential and realize their best value. The development of ICT makes access of knowledge easier. Education that simply conveys knowledge is meaningless and there is no retention of knowledge. Therefore, university education should change the teaching-learning proccess so that students will be able to set their own learning goals geared towards the requirement of the fourth industrial revolution. Teachers should set and observe the direction of students' learning and help them according to their individual capabilities.

Therefore, professors who coach architectural vista design should work with students throughout the course, from project objectives to building mass concepts, design development directions, and presentation methods based on final results, rather than merely teaching them by the book.

The evaluation should not be grade-oriented because students understand knowledge by discussing and analyzing what part of the analysis and evaluation was wrong and how it affected the result.

In competency-based education, each student sets and executes learning goals according to his or her abilities, so learning must be conducted in a variety of ways according to each student's inclinations until all major learning contents are understood.

Competence, which means proficiency in performing tasks, is visible and measurable, and can be improved through repetitive training or practice in a short period of time. In traditional industrial societies, this comprehension is an important factor, and we have summarized it in terms of specification. However, the education of future societies requires competency, which means confidence or potential ability to do something or act, which is not yet directly visible to the eyes as a part of teaching methods, making it difficult to improve in a short period of time.

Education in universities should be geared towards improving students 4IR-required competencies. Nowadays, universities declare that they will provide competency-based education through educational engineering and study various methods, however, the traditional education methods are still practiced by the professors. Their academic records are still based on the five competencies presented by the competency centers or other affiliated institutions.

In the Fourth Industrial Revolution, vocational training education changes from the existing instructor-centered to learner-centered, and from one-size-fits-all standardization to providing customized goods and services. Learners gain knowledge by collecting and integrating new 
information using problem-solving skills through critical thinking and subsequent investigation. In addition, the time has come to induce change from this passive way of accepting information to actively participating in it.

Universities should modify their teaching-learning methods to adapt to the changes in the society with the advent of the fourth industrial revolution.

\section{References}

[1] Ryu Tae-ho, Report card without grades, Korea: Kyung Hee University Publication and Culture Center, (2019)

[2] T. H. Yoo, The Fourth Industrial Revolution, The design and practice of vocational training courses for the development of core competencies in the 21st century, Competency Development Education Center in KoreaTech, (2020), http://www.dhnews.co.kr/news/articleView.html?idxno=126870

[3] Klaus Schwab, The fourth industrial revolution, by Klaus Schwab, (2016), https://www.weforum.org/about/thefourth-industrial-revolution-by-klaus-schwab

[4] World Economic Forum, The Future of Jobs, (2016), https://www3.weforum.org/docs/WEF_Future_of_Jobs.pdf

[5] Choi Yoon-kyung, NCS Vocational Basic Ability Improvement through the Liberal Curriculum of Specialized Universities, Research on Liberal Education, (2017), Vol.11, No.3, pp.525-554.

[6] Ministry of Education, NCS based Curriculum Guideline: Development, Operation and Evaluation, Quality Management. Korea: Ministry of Education, (2015) 